\title{
A literature review of complementary and alternative medicine used among diabetes mellitus patients
}

\author{
Anita Joeliantina', Oedojo Soedirham², Mangestuti Agil ${ }^{3}$, M. Bagus Qomaruddin², \\ Kusnanto Kusnanto ${ }^{4}$ \\ ${ }^{1}$ Department of Nursing, Health Polytechnic Ministry of Health, Indonesia \\ ${ }^{2}$ Faculty of Public Health, Airlangga University, Indonesia \\ ${ }^{3}$ Faculty of Pharmacy, Airlangga University, Indonesia \\ ${ }^{4}$ Faculty of Nursing, Airlangga University, Indonesia
}

\begin{tabular}{l} 
Article Info \\
\hline Article history: \\
Received Nov 16, 2018 \\
Revised Mar 20, 2019 \\
Accepted Apr 13, 2019 \\
\hline Keywords: \\
Alternative medicine, \\
Complementary medicine, \\
Diabetes mellitus, \\
Pattern use CAM \\
Traditional medicine
\end{tabular}

\begin{abstract}
Diabetes is a chronic disease that requires regular and sustainable health management that involves proper treatment. Some diabetic patients use complementary and alternative medicine (CAM), as well as conventional medicine, to maintain their health and control their blood sugar. This literature review aimed to 1) Determine the prevalence of CAM used by patients with diabetes, summarize and evaluate the CAM use that includes: characteristics, patterns, types and reasons. 2) Propose a conceptual model associated with CAM used by patients with diabetes. A Literature review was searched using an electronic database and published between 2005 and 2015 by using specific keywords. The number of literature review obtained as a search result is 17 articles from 14 countries. The prevalence of CAM used by patients with diabetes ranged from $16.6 \%$ to $76 \%$. Determinants associated with the CAM use were age, gender, family income, occupation, residence, and the characteristics of the disease, such as the length of time since diagnosed and complications. Most patients used CAM, along with the conventional treatment, and did not inform health professionals about the CAM use. The CAM use by patients with diabetes was relatively high and the confidence of patients believed the benefits of CAM. Therefore, integration with health professionals to develop CAM management is highly required.
\end{abstract}

Copyright $@ 2019$ Institute of Advanced Engineering and Science. All rights reserved.

\section{Corresponding Author:}

Anita Joeliantina,

Nursing Program at Health Polytechnic Ministry of Health Surabaya,

Jl. Mayjend. Prof. Dr. Moestopo No 8 C Surabaya, Indonesia.

E-mail address: nita.mukhlash@gmail.com

\section{INTRODUCTION}

Diabetes Mellitus (DM), as a chronic disease, is a group of metabolic diseases with a hyperglycemia characteristic that occurs due to abnormalities in insulin secretion, insulin action, or both [1-2]. DM is a major cause of morbidity and mortality worldwide and the prevalence keeps increasing. The prevalence of diabetes in the world for adults (aged 20-79 years) was $6.4 \%$ or about 285 million adults in 2010, and will increase to $7.7 \%$, approximately 439 million adults in 2030. Between 2010 and in 2030, there is a $69 \%$ increase in the number of adults with diabetes in developing countries and $20 \%$ increase in developed countries [3].

The main danger of DM is that it causes either acute or chronic complications. Acute complications include hypoglycemia, ketoacidosis, and a diabetic coma. Chronic complications are caused by high levels of blood glucose (hyperglycemia), including microvascular and macrovascular complications. Microvascular complications include nephropathy, retinopathy, and neuropathy, while macrovascular 
complications include atherosclerosis and cardiac ischemia that can create the risk of morbidity, mortality, and disability by 2-4 times in patients with diabetes mellitus [1, 4]. Approximately 70-80 percent of patients with diabetes mellitus died of vascular disease as a complication of diabetes [2].

Treatment for type 2 diabetes should be conducted in a sustainable manner for a long period. Patients with type 2 diabetes can take not only conventional medicine, but also complementary medicine as a complement of the conventional treatments that have been carried out. There is a tendency growing all over the world that patients with type 2 diabetes use or choose Complementary and Alternative Medicine (CAM) in order to improve their health status. Complementary medicine is often used in conjunction with conventional medicine but not as a substitute for conventional medicine. Meanwhile, alternative medicine is used as replacement of conventional treatment [4-8]. Of the patients who suffer from chronic diseases, diabetes is the highest CAM users which are $63 \%$, followed by $42.7 \%$ of RA, $26.2 \%$ of HIV, and $7.7 \%$ of epilepsy [9]. Patients with diabetes are ranked as the second for CAM users, which is $62.1 \%$ after hypertension $(63.8 \%)$, followed by migraine, chronic obstructive disease, gastrointestinal tract disease, and rheumatoid arthritis in using CAM [10].

NCCIH categorizes CAM into three main domains: natural products, mind and body practices, and other complementary health approaches. Natural products include a variety of products, such as herbs (also known as botanicals), vitamins and minerals, and probiotics. They are widely marketed, available to consumers, and often sold as a dietary supplement. The mind and body practices include a large and diverse group of procedures or techniques that are given or taught by trained practitioners or instructors, such as: yoga, chiropractic and osteopathic manipulation, meditation, massage therapy, acupuncture, and relaxation techniques. Other approaches to complementary medicine comprise the traditional medicine practices, Ayurvedic medicine, Chinese traditional medicine, homeopathy, and naturopathy [11]. The objectives of this article are to (a) Determine the prevalence, summarize, and explore to the behavior of using complementary and alternative medicine including: characteristics, patterns, types and reasons for the use in patients with type 2 diabetes based on various theories and research. (b) Propose a conceptual model associated with the use complementary and alternative medicine by patients with diabetes.

\section{RESEARCH METHOD}

This literature review was searched by using an electronic database such as Pro-Quest, Google Scholar, PubMed, Science-Direct, and hand-searching. The literature review used are articles published from 2005-2015. Keywords used to search were complementary and alternative medicine, diabetes mellitus, traditional medicine, and the pattern of complementary and alternative medicine. Literature works collected were as many as 280 abstracts subsequently selected according to inclusion criteria preset to compile this literature review. The inclusion criteria in this study were studies that explored CAM use by diabetic patients published between 2005-2015. Exclusion criteria were studies published before 2005, not using English, and types of qualitative research. From the search found 17 articles corresponding quantitative research. The review selection process can be seen in Figure 1.

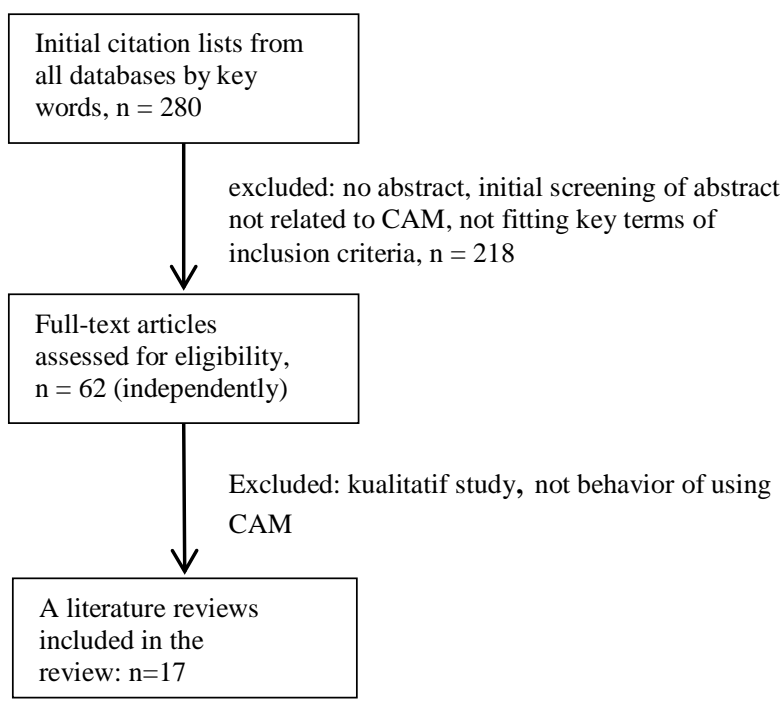

Figure 1. Selection process of literature review 


\section{LIMITATIONS OF REVIEW}

This review includes research that focuses on the behavior of CAM use by diabetics. This review is not a literature review of active compounds from herbs, the efficacy and safety of CAM, but only research on the behavior of diabetic patients in using CAM. Formal quality assessment to determine which research was used independently. Some studies that shown design bias, selection and measurement were included because they provide useful insights both in terms of definitions of terms or because they provide information about disclosing the behavior of diabetic patients using CAM.

\section{RESULTS AND ANALYSIS}

\subsection{The prevalence of cam use}

The results of this literature review describe the prevalence of CAM use of various countries. Most studies used cross-sectional study/survey with various periods, ranging from 1 month to 2 years. The prevalence of CAM use still varies, ranging from $16.6 \%$ in Jordan up to $76 \%$ in the Srilangka [4, 8]. This variation is due to many factors that influence CAM use by patients with diabetes, the definition of CAM, and the survey method used by researchers.

Figure 1 shows the prevalence of diabetic patients who use CAM from 14 countries, where the prevalence of the CAM use by patients with diabetes was over $40 \%$ in 12 countries so that it can be said that the prevalence of the CAM use by patients with diabetes is relatively high [4-5, 12-21]. The prevalence of CAM use in this literature review is consistent with other literature reviews showing that the range of the prevalence of CAM use by patients with diabetes is from $17 \%$ up to $72.8 \%$ [22].

\subsection{CAM use patterns}

CAM use patterns are behaviors that show a tendency to diabetic patients using CAM as a complement to conventional treatment being undertaken. In this literature review, the patterns of CAM use shown by diabetic patients are: (a) Mostly, CAM is used in conjunction with conventional medicine/allopathy. (b) It does not change their treatment, both in the treatment schedule or doses. (c) Reducing one dose or more of conventional treatment. (d) Using conventional medicine and CAM in different times, and (e) Stopping taking the conventional medicine when using CAM [12-13, 18, 23-25]. Diabetic patients, most use CAM as a complementary or supplementary to their conventional treatment $[8,23,26]$, and small percentage use CAM only [8]. Diabetic patients use at least one type of CAM modalities, or combining two or more of the CAM modalities [15, 19, 22-23]. Of all patients with diabetes in Sri Lanka using CAM, 49 patients used one type of CAM, 86 patients used the two types, 52 used three types, and 6 patients used more than 3 different types [4].

Over $60 \%$ of patients with diabetes who used CAM modalities did not inform their doctors or health professionals. Only $24.6 \%-45 \%$ did so $[12,16,18,20,22,25-26]$. Someone who states that at least $63 \%$ of the general population does not disclose the CAM use therapies to their doctors because: a) They have never thought of it. b) They feel the CAM use is secure, so there is no need to discuss its use. c) Health care professionals do not ask about their using CAM. d) Health professional will prevent the CAM use. e) There is not enough time to discuss the CAM use. f) Health professionals do not have adequate knowledge about CAM [7, 13]. Meanwhile, patients with diabetes who informed their decision to use CAM have received relatively negative responses from health professionals, namely a) They state that it is entirely patients business and offers not to comment on the CAM use. b) They warn the possible side effects of the CAM use. c) They discourage patients to consume. d) Just few health professionals encourage them to use CAM $[22,27]$.

\subsection{Individual characteristics}

Gender, age, education, income, religion, marital status, and family size are the determinants predicted to affect diabetic patients to use CAM. Table 1 shows that female respondents use CAM more than men, but as many as six research shows that gender is not significantly associated with the CAM use $[12,15,18-19,22-23]$. Meanwhile, 5 studies show a significant relationship between sex and the CAM use $[4-5,14,16,20]$. The patients with diabetes at age in this review were mostly over 40 years old. The age category varies from each study. The age of diabetic patients showing a significant effect on the CAM use was only found in the two studies, namely, in Taiwan and in the US [14, 22]. Prevalence of use of CAM by diabetic patients from several countries shown in Figure 2. 


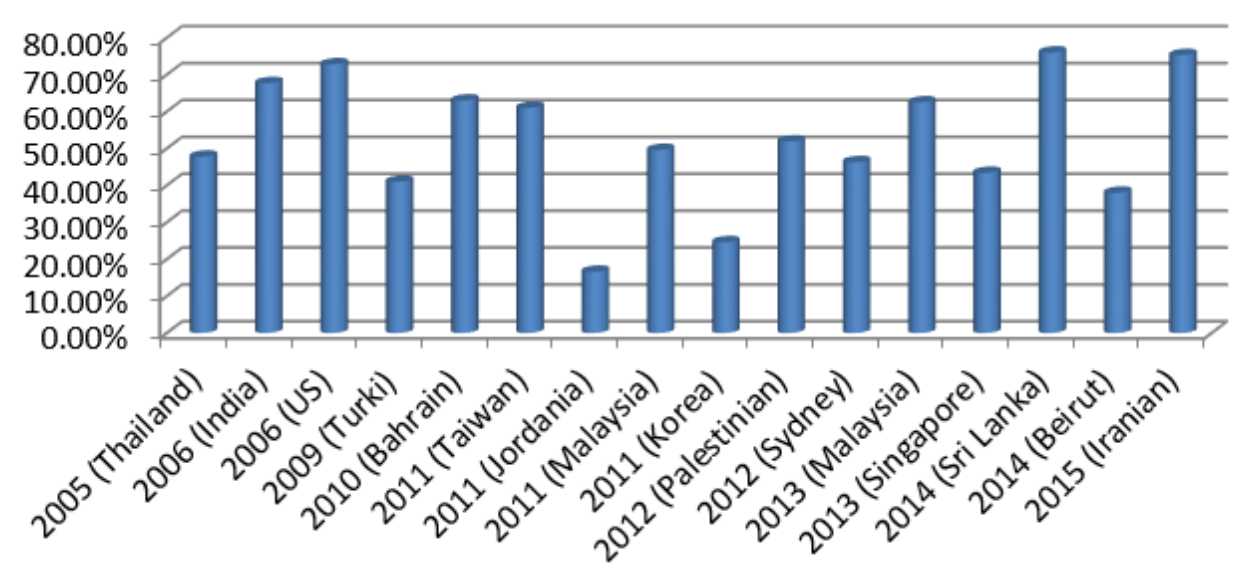

Figure 2. Prevalence of use of CAM by diabetic patients from several countries

These results illustrate that age is not a dominant factor that affects a person on CAM use. Only four studies showed that education that has a significant influence on CAM use by patients with diabetes [13-15, 26]. Likewise, high income also showed a significant effect only in 4 studies [5, 12, 20, 26]. Characteristic of the disease in this literature is limited only to the suffering duration and complications. Suffering duration is not significantly associated with CAM use. It can be seen in studies conducted to Iranian $p=0.64$, Sydney $p=0.603$, Palestinian $p=0.874$, and $p=0.64$ Thailand $[12,18-19,23]$. Meanwhile, the study results showing a significant relationship between suffering duration of diabetes and the CAM use were a study in Bahrain $(\mathrm{p}=0.008)$, Turkey $(\mathrm{p}=0.0001)$, and Beirut: the longer the duration of diabetes the higher were the odds of CAM use with patients diagnosed for a period over 15 years having the highest odds $(\mathrm{OR}=3.37, \mathrm{CI}=1.56-7.29)[15-16,27]$. The suffering duration is associated with the CAM use because, suffering a chronic disease, the patients might get bored with conventional medicine. The relationship between diabetes complications and the CAM use has been inconsistent. There are two studies showing a relationship between complications and the CAM use, in Iranian $(\mathrm{p}=0.05)$ and Bahrain $(p=0.00002)[16,23]$. Three studies show that there is no relationship between the diabetes complications and the CAM use [4, 18-19]. Diabetes complications are significantly related to the CAM use, based on studies conducted in Beirut, Lebanon [27]. Patients with neuropathic complications use CAM more than those without neuropathy [28].

Table 1. Research report on the use of CAM by patients with diabetes

\begin{tabular}{|c|c|c|c|c|c|c|}
\hline $\begin{array}{l}\text { Author, } \\
\text { Country }\end{array}$ & $\mathrm{N}$ & $\begin{array}{c}\text { Method \& } \\
\text { sampling design }\end{array}$ & Time frame & $\begin{array}{c}\text { Prevalence of } \\
\text { CAM use }\end{array}$ & $\begin{array}{l}\text { Use rate } \\
\text { of CAM }\end{array}$ & Type of CAM \\
\hline $\begin{array}{l}\text { (Moolasarn } \\
\text { and Ms, } \\
\text { 2005) } \\
\text { Thailand }\end{array}$ & 159 & $\begin{array}{l}\text { Cross sectional } \\
\text { survey, }\end{array}$ & $\begin{array}{l}\text { December } \\
2003 \text { to } \\
\text { January } \\
2004\end{array}$ & $\begin{array}{l}47.8 \% \\
(\mathrm{~N}=76)\end{array}$ & $\begin{array}{l}\text { Past } 3 \\
\text { months }\end{array}$ & $\begin{array}{c}\text { Yoga } 46 \% \text {, Unchanged form of herbal } \\
\text { medicine } 42.1 \% \text {, changed form of } \\
\text { herbal medicine } 25 \% \text {, Acupuncture } \\
\text { /Acupressure } 10.5 \% \text {, Mental therapy } \\
7.9 \% \text {, diet supplementary } 5.3 \% \text {, oil } \\
\text { message } 2.6 \% \text {, others } 1.3 \%\end{array}$ \\
\hline $\begin{array}{l}\text { (Kumar, } \\
\text { Bajaj and } \\
\text { Mehrotra, } \\
\text { 2006), } \\
\text { India }\end{array}$ & 493 & $\begin{array}{l}\text { Cross sectional } \\
\text { study, } \\
\text { systematic } \\
\text { sampling }\end{array}$ & 1999- 2001 & $\begin{array}{c}67.7 \% \\
(\mathrm{~N}=334)\end{array}$ & $\begin{array}{l}\text { aware of } \\
\text { CAM, } \\
\text { and } \\
\text { currently } \\
\text { using } \\
\text { CAM }\end{array}$ & $\begin{array}{c}\text { Naturopathy } 97.3 \%(n=325), \text { Ayurveda } \\
16.2 \%(n=54), \text { Homeopathy } 12.9 \% \\
(n=43), \text { Acupressure } 2.7 \%(n=9), \\
\text { others } 3.0 \%(n=10)\end{array}$ \\
\hline $\begin{array}{l}\text { (Bell et al., } \\
\text { 2006), } \\
\text { US }\end{array}$ & $\begin{array}{l}31.004 \\
\text { DM } \\
2.479 \\
\text { No DM, } \\
28.526\end{array}$ & $\begin{array}{l}\text { Data from } \\
\text { NHIS }\end{array}$ & $\begin{array}{l}\text { Data from } \\
\text { NHIS } 2002\end{array}$ & $\begin{array}{c}72.8 \% \\
(\mathrm{~N}=1.781)\end{array}$ & $\begin{array}{l}\text { within } \\
\text { the past } \\
\text { year }\end{array}$ & $\begin{array}{c}\text { Self- prayer } 61.2 \% \text {, other prayer } 39 \% \text {, } \\
\text { prayer group } 16.2 \% \text {, natural product } \\
15.7 \% \text {, massage } 3.1 \% \text {, relaxation } \\
\text { techniques } 12.7 \% \text {, others }\end{array}$ \\
\hline $\begin{array}{l}\text { (Ceylan et al, } \\
\text { 2009), } \\
\text { Turkey }\end{array}$ & 371 & $\begin{array}{l}\text { Cross sectional } \\
\text { study, survey } \\
\text { questionnaire }\end{array}$ & $\begin{array}{l}\text { January } \\
2006 \text { to } \\
\text { December } \\
2006\end{array}$ & $\begin{array}{c}41 \% \\
(\mathrm{~N}=152 \\
\mathrm{F}=104 \\
\mathrm{M}=48)\end{array}$ & NM & $\begin{array}{l}\text { Herbal preparation } 88.1 \% \text {, } \\
\text { Acupuncture and meditation practises } \\
5.3 \% \text {, herbal preparation and folk } \\
\text { medicine practices } 3.3 \% \text {, herbal }\end{array}$ \\
\hline
\end{tabular}

Int. J. Public Health Sci. Vol. 8, No. 2, June 2019: 277 - 286 


\begin{tabular}{|c|c|c|c|c|c|c|}
\hline $\begin{array}{l}\text { Author, } \\
\text { Country }\end{array}$ & $\mathrm{N}$ & $\begin{array}{c}\text { Method \& } \\
\text { sampling design }\end{array}$ & Time frame & $\begin{array}{l}\text { Prevalence of } \\
\text { CAM use }\end{array}$ & $\begin{array}{l}\text { Use rate } \\
\text { of CAM }\end{array}$ & Type of CAM \\
\hline & & & & & & $\begin{array}{l}\text { preparation and acupuncture } \\
\text { medication } 3.3 \%\end{array}$ \\
\hline & & & & & & $\begin{array}{l}\text { Natural product } \\
\text { Natural product with using: }\end{array}$ \\
\hline $\begin{array}{l}\text { (Khalaf \& } \\
\text { Withord, } \\
\text { 2010), }\end{array}$ & 402 & $\begin{array}{l}\text { Cross sectional } \\
\text { study, } \\
\text { convenience }\end{array}$ & NM & $\begin{array}{c}63 \% \\
(\mathrm{~N}=252 \\
\mathrm{F}=149\end{array}$ & $\begin{array}{l}\text { The } \\
\text { previous } \\
12\end{array}$ & $\begin{array}{l}\text { alternative and medical } \\
\text { practices } \mathrm{n}=80.32 \%, \\
\text { mind-body interventions } \\
\mathrm{n}=24.10 \%\end{array}$ \\
\hline Bahrain & & sampling & & $\mathrm{M}=103)$ & months & $\begin{array}{l}\text { manipulative and body } \\
\text { based } n=78.31 \% \\
\text { energy therapy } n=8.3 \%\end{array}$ \\
\hline $\begin{array}{l}\text { (Hasan, et } \\
\text { al., 2011), } \\
\text { Malaysia }\end{array}$ & 230 & $\begin{array}{l}\text { Case-control } \\
\text { study, random } \\
\text { sampling }\end{array}$ & NM & $\begin{array}{c}49.6 \% \\
N=144 \\
F=54 \\
M=60\end{array}$ & NM & $\begin{array}{c}\text { Vitamin } 57.9 \% \text {, ginseng } 12.3 \%, \text { yoga } \\
7.9 \%\end{array}$ \\
\hline $\begin{array}{l}\text { (Hsiao-yun, } \\
\text { Wallis and } \\
\text { Tiralongo, } \\
\text { 2011), } \\
\text { Taiwan }\end{array}$ & 326 & $\begin{array}{l}\text { A cross } \\
\text { sectional } \\
\text { survey, } \\
\text { structure } \\
\text { interview, } \\
\text { simple random } \\
\text { sampling }\end{array}$ & $\begin{array}{l}\text { July } 2006 \\
\text { and } \\
\text { February } \\
2007\end{array}$ & $\begin{array}{l}\text { Before: } \\
22.7 \% \\
(\mathrm{~N}=74) \\
\text { After: } 61 \% \\
(\mathrm{~N}=197)\end{array}$ & $\begin{array}{l}\text { The } \\
\text { previous } \\
12 \\
\text { months }\end{array}$ & $\begin{array}{c}\text { Use of CREAM after being diagnosed } \\
\text { with diabetes: Acupuncture } 6.7 \% \text {, } \\
\text { chines herbal medicines } 27.9 \%, \\
\text { nutritional supplement } 41.1 \% \text {, diet } \\
\text { modification } 13.2 \% \text {, non -chines herbs } \\
3.4 \% \text {, cupping, scraping } 6.4 \% \text {, } \\
\text { manipulative-based therapy } 13.5 \% \text {, } \\
\text { folk therapies } 0.6 \% \text {, bio-field therapy } \\
9.2 \% \text {, bio-electromagnetic based } \\
\text { therapies } 10.1 \% \text {, supernatural healings } \\
11.0 \% \text {, mind-body therapies } 3.7 \%\end{array}$ \\
\hline $\begin{array}{l}\text { (Wazaify, et } \\
\text { al., 2011), } \\
\text { Jordan }\end{array}$ & 1000 & $\begin{array}{l}\text { Cross-sectional } \\
\text { survey, random } \\
\text { sampling }\end{array}$ & $\begin{array}{l}\text { March } \\
2009 \text { to } \\
\text { September } \\
2009\end{array}$ & $\begin{array}{c}16.6 \% \\
N=166 \\
F=99 \\
M=67\end{array}$ & NM & $\begin{array}{c}\text { Herbal } 93.4 \% \text {, the plants in the form of } \\
\text { infusion 93.9\% (green tea, aniseed, } \\
\text { ginger, chamomile, sage, fenugreek, } \\
\text { nigella, black-seed, white lupin, } \\
\text { germander, garlic, cinnamon, olive } \\
\text { leaves) }\end{array}$ \\
\hline $\begin{array}{l}\text { (Kim, et al., } \\
\text { 2011), } \\
\text { KNDP, } \\
\text { Korea }\end{array}$ & 2752 & $\begin{array}{l}\text { Cross sectional } \\
\text { study, hospital } \\
\text { electronic } \\
\text { database }\end{array}$ & $\begin{array}{l}\text { KNDP } \\
2005 \text { and } \\
2009\end{array}$ & $\begin{array}{c}24.6 \% \\
(\mathrm{~N}=677 \\
\mathrm{F}=290 \\
\mathrm{M}=387)\end{array}$ & $\begin{array}{c}\text { The past } \\
1 \text { year up } \\
\text { until the } \\
\text { time of } \\
\text { their } \\
\text { initial } \\
\text { enrollme } \\
\text { nt }\end{array}$ & $\begin{array}{l}\text { Red ginseng, herbal medicine, } \\
\text { silkworm, others }\end{array}$ \\
\hline $\begin{array}{l}\text { (Ali-Stayeh, } \\
\text { Jamous and } \\
\text { Jamous, } \\
\text { 2012), } \\
\text { Palestinian }\end{array}$ & 1883 & $\begin{array}{l}\text { Cross-sectional } \\
\text { study, random } \\
\text { sampling }\end{array}$ & $\begin{array}{l}\text { August } \\
2010 \text { until } \\
\text { May } 2011\end{array}$ & $\begin{array}{l}51.9 \% \\
N=977 \\
F=519 \\
M=457\end{array}$ & NM & $\begin{array}{c}\text { The main herb as CAM: } \\
\text { Trigonella berythea } 19.6 \%(\mathrm{n}=191) \text {, } \\
\text { Rosmarinus officinalis } 13.5 \%(\mathrm{n}=132) \text {, } \\
\text { Teucrium capitatum } 11.4 \%(\mathrm{n}=111) \text {, } \\
\text { Cinnamomun zeylanicum } 10.8 \% \\
(\mathrm{n}=105) \text {, others plan } 44.7 \%(\mathrm{n}=438) \\
\text { Other CAM modalities: } \\
\text { Prayer } 70 \%(\mathrm{n}=684) \text {, vitamins and } \\
\text { mineral } 9.9 \%(\mathrm{n}=97), \text { exercise } 9.2 \% \\
(\mathrm{n}=90) \text {, others }(\mathrm{n}=11)\end{array}$ \\
\hline $\begin{array}{l}\text { (Manya, } \\
\text { Champion } \\
\text { and Dunning, } \\
\text { 2012), } \\
\text { Sydney }\end{array}$ & 69 & $\begin{array}{l}\text { A cross- } \\
\text { sectional } \\
\text { survey, two } \\
\text { stage sampling } \\
\text { design }\end{array}$ & $\begin{array}{l}\text { June and } \\
\text { August } \\
2008\end{array}$ & $\begin{array}{l}46.3 \% \\
N=32 \\
F=15 \\
M=17\end{array}$ & NM & $\begin{array}{c}\text { The most commonly used CAM to } \\
\text { treat diabetes: } \\
\text { Multivitamin } 40 \% \text {, Cinnamon } 25 \% \text {, } \\
\text { Co-enzyme Q10 25\%, Prayer 25\%, } \\
\text { others }\end{array}$ \\
\hline $\begin{array}{l}\text { (Ching et al, } \\
\text { 2013), } \\
\text { Malaysia }\end{array}$ & 240 & $\begin{array}{l}\text { A cross- } \\
\text { sectional study, } \\
\text { random } \\
\text { sampling } \\
\text { method }\end{array}$ & May 2011 & $\begin{array}{l}62.5 \% \\
N=150 \\
F=96 \\
M=54\end{array}$ & NM & $\begin{array}{l}\text { Biological based therapy like herbal } \\
\text { products } 80 \%(n=120) \text {, manipulative } \\
\text { and body-based systems } 14.7 \%(n=22) \text {, } \\
\text { alternative medical system } 7.3 \% \\
(n=11) \text {, energy therapies } 14 \%(n=21) \text {, } \\
\text { mind-body interventions } 2.7 \%(n=4)\end{array}$ \\
\hline $\begin{array}{l}\text { (Fan } \text { et al., } \\
\text { 2013), } \\
\text { Singapore }\end{array}$ & 304 & $\begin{array}{l}\text { A Cross- } \\
\text { sectional } \\
\text { descriptive } \\
\text { design, } \\
\text { convenience } \\
\text { sampling }\end{array}$ & NM & $\begin{array}{c}43.4 \% \\
N=132 \\
F=67 \\
M=64\end{array}$ & NM & $\begin{array}{c}\text { Nutritional supplements } 55.3 \%(n=73) \text {, } \\
\text { Chinese herbal medicine } 29.5 \% \\
(n=39), \text { massage } 28 \%(n=37)\end{array}$ \\
\hline $\begin{array}{l}\text { (Mitha, et al., } \\
\text { 201)3, } \\
\text { Malaysia }\end{array}$ & 256 & $\begin{array}{l}\text { Cross-sectional } \\
\text { study, } \\
\text { convenience } \\
\text { sampling }\end{array}$ & $\begin{array}{l}\text { August } \\
2012 \text { to } \\
\text { October } \\
2012\end{array}$ & $\begin{array}{l}N=256 \\
F=164 \\
M=92\end{array}$ & $\begin{array}{l}\text { The past } \\
3 \text { months }\end{array}$ & $\begin{array}{l}\text { TCM } 31 \% \text {, supplement } 18 \% \text {, TIM } \\
\text { 14\%, Faith healing } 10 \%, \text { Nutritional } \\
\text { therapy } 9 \% \text {, others }\end{array}$ \\
\hline (Medagama & 252 & A cross, & April and & $76 \%$ & NM & Bitter gourd $50.8 \%(n=128)$, Ivy gourd \\
\hline
\end{tabular}




\begin{tabular}{|c|c|c|c|c|c|c|}
\hline $\begin{array}{l}\text { Author, } \\
\text { Country }\end{array}$ & $\mathrm{N}$ & $\begin{array}{c}\text { Method \& } \\
\text { sampling design }\end{array}$ & Time frame & $\begin{array}{l}\text { Prevalence of } \\
\text { CAM use }\end{array}$ & $\begin{array}{l}\text { Use rate } \\
\text { of CAM }\end{array}$ & Type of CAM \\
\hline $\begin{array}{c}\text { et al., 2014), } \\
\text { Sri Lanka }\end{array}$ & & $\begin{array}{l}\text { sectional } \\
\text { survey, } \\
\text { randomly } \\
\text { selected }\end{array}$ & $\begin{array}{c}\text { August } \\
2012\end{array}$ & $\begin{array}{l}\mathrm{N}=192 \\
\mathrm{~F}=139 \\
\mathrm{M}=53\end{array}$ & & $\begin{array}{c}\text { leaves } 44.8 \%(n=113) \text {, crepe ginger } \\
\text { leaves } 36.5 \%(n=92) \text {, salacia reticulate } \\
6.7 \%(n=17), \text { fenugreek } 2 \%(n=5)\end{array}$ \\
\hline $\begin{array}{l}\text { (Naja, et al., } \\
\text { 2014), Beirut }\end{array}$ & 333 & $\begin{array}{c}\text { Cross-sectional } \\
\text { study }\end{array}$ & $\begin{array}{l}\text { August } \\
2010 \text { and } \\
\text { January } \\
2011\end{array}$ & $\begin{array}{c}38 \% \\
\mathrm{~N}=127\end{array}$ & NM & $\begin{array}{c}\text { Folk food and herbal } 81 \% \text {, natural } \\
\text { product } 28 \% \text {, spiritual healing } 11.8 \% \text {, } \\
\text { vitamin and mineral } 3 \%\end{array}$ \\
\hline $\begin{array}{l}\text { (Hashempur } \\
\text { et al., 2015), } \\
\text { Iranian }\end{array}$ & 239 & $\begin{array}{l}\text { Cross sectional } \\
\text { study, } \\
\text { convenient } \\
\text { sampling }\end{array}$ & $\begin{array}{l}\text { June to } \\
\text { September } \\
2011\end{array}$ & $\begin{array}{l}75.3 \% \\
\mathrm{~N}=180 \\
\mathrm{~F}=123 \\
\mathrm{M}=56\end{array}$ & $\begin{array}{c}\text { The last } \\
\text { year }\end{array}$ & $\begin{array}{l}\text { Herbal preparations } 97.7 \%(n=176) \text {, } \\
\text { cupping } 8.3 \%(n=15), \text { Acupuncture } \\
2.7 \%(n=5), \text { mind-body } 0.55 \%(n=1)\end{array}$ \\
\hline
\end{tabular}

$\mathrm{N}=$ number of sample, $\mathrm{NM}=$ not mentioned, $\mathrm{F}=$ female, $\mathrm{M}=$ male

\subsection{Types of CAM}

CAM widely used by patients with diabetes and found in this literature review, as shown in Table 1, are herbs, vitamins, and prayers. In the US, the most widely used CAM by patients with diabetes are herbs, supplements (vitamins and minerals), and mind body therapies [7]. Overall, Table 1 shows the types of CAM used by many diabetic patients in many countries. In Turkey many uses herbal preparations such as Origanum vulgare, pomegranate syrup, stinging nettle (nettle leaf), dog rose (rosa canina), Chervil, Cinnamon, and bitter almond [15]. In Bahrain, the natural ingredients used are garlic, bitter melon, cinnamon, and fenugreek. Trigonella berythea, Rosmarius officinalis, Teucrium capitatum, and Cinnamomun zeylanicum are four main herbs that are widely used by patients with diabetes in Palestine, out of 100 plants from 44 botanical families. In Sydney, herbs used are cinnamon, garlic, gymnena slyveste, fenugreek, and American ginseng. Herb used in Malaysia is bitter gourd, cat's whiskers, garlic, Sabah snake grass, basil leaf, and ginseng. Bitter gourd, crepe ginger, ivy gourd, fenugreek, and Salacia reticulate are herbs used by patients with diabetes in Sri Lanka. In Iranian, 4 main herbs used are cinnamon, ginger, fenugreek, and camellia sinensis. From these studies, it can be concluded that the most widely used herbs are cinnamon, garlic, bitter gourd, ginseng, fenugreek, ginger, and and nutritional supplements [4-5, 15-16, 18-19, 23]. Chronic diseases, such as diabetes, are associated with decreasing quality of life, and psychological problems, such as anxiety and depression. Mind-body therapies have a psychological effect that can help patients cope with the disease and improve their mood and quality of life. Patients with diabetes, based on the clinical trials, have shown improved quality of life and stress reduction with yoga and tai chi. The intensity of yoga and tai chi practices has been categorized as a low to medium intensity. During the clinical trials with controls, either yoga or tai chi consistently shows a significant long-term improvement in controlling blood glucose or A1C [7]. The safety CAM use is important for patients who take these medications, as well as for health care professionals, especially because of the growing popularity of CAM use by diabetics. A considerable percentage of diabetes patients who used CAM in conjunction with conventional medicine rather than as a substitute. This situation allows for side effects interactions of CAM with medical treatment, so this should be considered [28].

\subsection{Resources of CAM}

The informational beliefs are due to the direct, positive experiences of information sources about the CAM use. Information sources about the CAM use, mostly obtained from a friend, are shown by 5 studies, namely, the one in Beirut, another in Singapore (57.44\%), another in Malaysia (32.1\%), and the other in India $(36.4 \%)[5,13,20,26-27]$. Meanwhile, the information sources that come mostly from families are shown by 3 studies, namely, one study in Palestine $(40.2 \%)$, another in Jordan $(41 \%)$, and the other in Taiwan $(36 \%)$ [18, 21-22]. Other sources of information are obtained from the media and CAM practices. Conclusion derived from the sources of information is that friends are the main source of information that can affect diabetic patients to use CAM.

\subsection{Reason for using CAM}

CAM users expressed a variety of reasons why they are using CAM. This literature review will outline those various reasons. Diabetic patients' reasons on using CAM is the quality and safety of CAM (63.2\%), an additional treatment for their diabetes (53.5\%), family history in using CAM (21.9\%), fewer side effects of CAM (20.2\%), allopathic treatment failure (16.7\%), and some other reasons [26]. A belief that CAM can control diabetes, the good example of other CAM users, the ease of getting CAM, and the affordable price are also the reasons for diabetic patients to use CAM [5]. The diabetic patients' strongest 
belief in using is that CAM is safer $(n=178,69.5 \%)$; CAM has few side effects ( $n=201,78.5 \%)$; CAM will maintain their health $(n=212,82.8 \%)$, and CAM is chosen because allopathic medicine is less effective [31]. There is also a belief that CAM has a synergistic effect with conventional medicine [23]. Explains that the reasons for diabetic patients using CAM are to control diabetes (24.9\%), to treat complications $(3.2 \%)$, and mostly, (71.9\%) other conditions associated with health [22].

\section{DISCUSSION}

Diabetes is a chronic condition that requires both lifestyle and knowledge modification in order to acquire and apply skills that will enable effective self-care activities on a long-term basis. Type 2 diabetes is a chronic disease that requires regular and sustainable health management that involves proper treatment $[22,29]$. Patients with diabetes, besides using conventional treatments, also use complementary and alternative medicine to supplement the medication. There is a worldwide growing trend that diabetic patients use complementary and alternative medicine in order to improve their health status.

The results of the analysis of several studies in this review shows that there are several determinants associated with the CAM use, namely, the characteristics of the individuals (age, gender, marital status, ethnicity, education level, family income, place of residence, and sources of information) and the characteristics of diabetes (types of diabetes, duration of diagnosis, complications, complaints, and family history). The CAM use by patients with diabetes as an attempt to improve their health status can be evaluated from the types of medicine selected, patterns of use, and the reasons for using CAM. The types of CAM selected refer to NCCIH (2015) stating that they are a product of nature, mind and body practices, and other complementary health approaches. CAM patterns of use include the first time of using CAM (before/after diagnosis), the number of the types of CAM used, schedule of CAM use, and a notification to healthcare officers $[20,22]$.

The reasons for using CAM by patients with diabetes vary such as the impact on health status, benefits, side effects, ease access and costs, the development of the incidence of complications, and experiences of the previous treatment $[5,26-27,30]$. The health status of diabetic patients showing efficacy of the CAM use was evaluated on a satisfaction using CAM and the patient's health status. Patients' satisfaction in using the CAM includes efficacy and safety of CAM selected. Health status includes the quality of life and the regulation of blood glucose (blood sugar levels and A1C). Schematically, the relationship between the determinants and the CAM use by patients with diabetes can be seen in Figure 2.

Factors of social support and individual beliefs affect diabetic patients in deciding whether to use CAM or not [22]. It is generally believed that social support is crucial to encourage someone to have positive health behavior and conduct an effective treatment in acute and chronic diseases [31]. Family support also influences a person to choose complementary and alternative medicine on the types of biological treatment and the manipulation of the body [32]. Family support for T2DM patients who use herbs is to give permission to use herbs, remind time of health control, provide information about herbs, and help prepare herbal preparations [33]. People with positive attitudes toward CAM and those with high family support are more likely to use CAM and more involved in self-care behaviors [22].

This literature review illustrates that the CAM is used as a complementary treatment. Although the prevalence of CAM users still vary, it remains necessary to have enough information about the efficacy, safety, and ways of presentation for CAM users. The majority of diabetic patients who use CAM do not tell doctors or health workers. The reasons why diabetic patients CAM users do so are that health professionals would prevent the CAM use and that they do not have adequate knowledge about CAM. From those reasons, it is necessary for the government to set health policy on the CAM use in health facilities [22].

This literature review still has various limitations. The limitation is that this review is based on a variety of research using sampling techniques and sample size varied, so that the significance level obtained is very relative influenced by both. The absence of variable that shows how much social support especially from families and health professionals in the use of CAM, so that patients can determine or make decisions appropriately in using both CAM type, frequency, and time use. Evaluation of the use of CAM is required to determine the effectiveness of using CAM. Such an evaluation can be seen in terms of the satisfaction of the use of CAM or the health status of patients using CAM. 


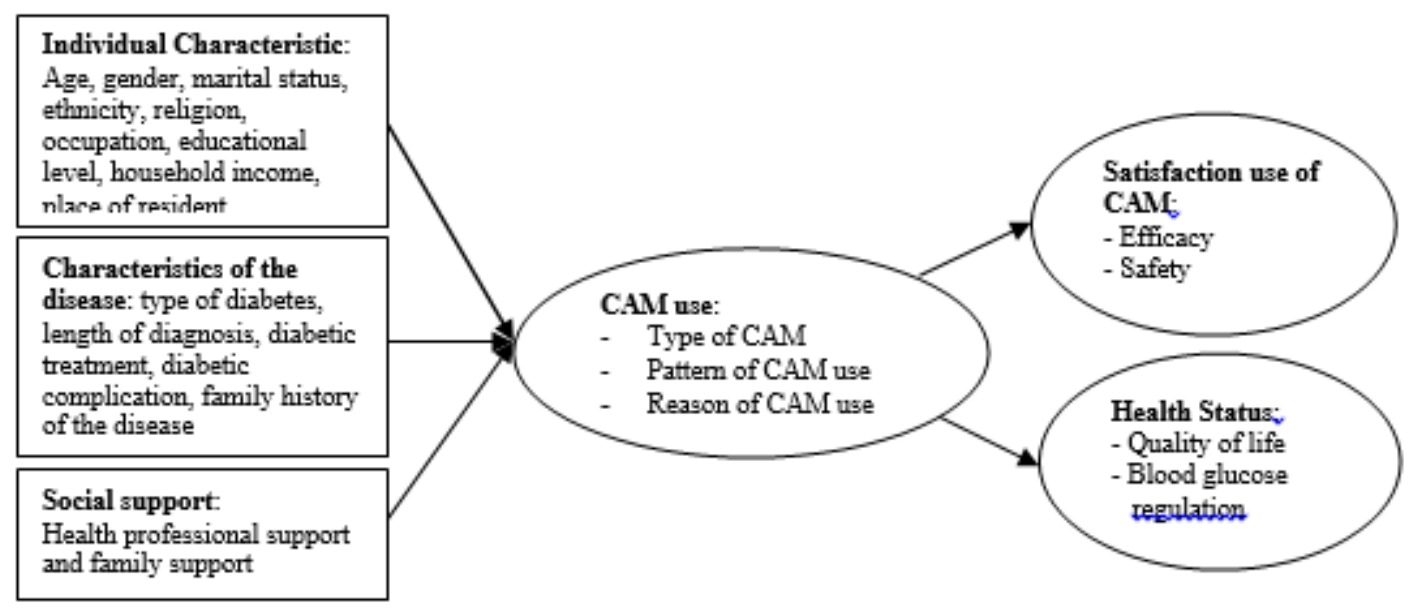

Figure 3. Conceptual model of the use of CAM by patients with diabetes

\section{IMPLICATION}

The CAM use by patients with diabetes can have implications for either the patient as an individual, healthcare professionals and government as a decision maker. Complementary and alternative medicine in Indonesia has been regulated in the Regulation of the Minister of Health of the Republic of Indonesia number 1109 / MENKES / PER / IX / 2007 concerning the Implementation of Alternative-Complementary Medicine in Health Service Facilities. CAM is categorized as complementary, alternative, and integrative, depending on how a person uses the CAM. If someone is using CAM in conjunction with conventional treatment, they will use complementary medicine.

This literature review illustrates that the CAM is used as a complementary treatment. Although the prevalence of CAM users still vary, it remains necessary to have enough information about the efficacy, safety, and ways of presentation for CAM users. The majority of diabetic patients who use CAM do not tell doctors or health workers. The reasons why diabetic patients CAM users do so are that health professionals would prevent the CAM use and that they do not have adequate knowledge about CAM. From those reasons, it is necessary for the government to set health policy on the CAM use in health facilities [17]. It is also necessary to improve health professionals' knowledge of integrative medicine. The Integration of various practices, therapies, and beliefs in CAM with conventional healthcare provides great potential for a better healthcare system, such as expanding treatment options, increasing the satisfaction of patients and providers, and providing better therapies [34]. The combination of conventional and complementary medicine often produces better results than conventional therapy alone, especially the reduction of negative side effects from the treatment. Synergy on integrative treatments in many clinical situations would offer various benefits, including the acceleration of the recovery from surgery, reduction on the dependency on drugs, and the reduction of side effects [34].

\section{CONCLUSION}

CAM can be defined as complementary medicine, alternative, and integrative depending on the patients that use it. CAM is widely used by people with chronic diseases. Diabetes mellitus as a chronic disease requires special attention in terms of treatment and management. One treatment that is chosen by the patient with diabetes is CAM. In this review, the diabetic patients use CAM as complementary and alternative medicine, but not as integrative medicine. Further research is needed on CAM as an integrative treatment in diabetic patients. Medical pluralism gives an insight into the use of conventional treatments and CAM systems that are widely used by patients with chronic diseases. CAM widely used by patients with diabetes is natural products. Therefore, further research is required to reveal the efficacy and safety of the CAM use. The successful use of CAM can be evaluated on the regulation of blood glucose. Furthermore, CAM management as an integrative treatment by healthcare professionals is also required. For this purpose, this literature review offers a conceptual model as a framework for further research on the CAM use. 


\section{REFERENCES}

[1] American Diabetes Association AD, Li R, Zhang P, Barker L, Chowdhry F, et al. Standartds of medical care in diabetes, 36 Suppl 1: S11-66, 2013.

[2] International Diabetes Federation, Diabetes Atlas., Seventh edition 2015.

[3] Shaw JE, Sicree RA, Zimmet PZ. Global estimates of the prevalence of diabetes for 2010 and 2030. Diabetes Res Clin Pract. 2010.

[4] Medagama AB, Bandara R, Abeysekera RA, Imbulpitiya B, Pushpakumari T. Use of complementary and alternative medicines (CAMs) among type 2 diabetes patients in Sri Lanka: A Cross sectional survey. BMC Complement Altern Med, 14(1), 2014.

[5] Ching SM, Zakaria ZA, Paimin F, Jalalian M. Complementary alternative medicine use among patients with type 2 diabetes mellitus in the primary care setting: a cross-sectional study in Malaysia. BMC Complement Altern Med, 13(1):148, 2013.

[6] Khalil SHA, Zaki A, Ibrahim AM, El-Moughazi AM, Khater AM, Youssef AM, et al. Pattern of use of complementary and alternative medicine among type 2 diabetes mellitus patients in Alexandria, Egypt. J Egypt Public Health Assoc, 88(3):137-42, 2013.

[7] Birdee GS, Yeh G. Complementary and alternative medicine therapies for diabetes: A Clinical Review. Clin Diabetes, 28(4):147-55, 2010.

[8] Vishnu N, Mini GK, Thankappan KR. Complementary and alternative medicine use by diabetes patients in Kerala, India, Glob Heal Epidemiol Genomics, 2, e6, pp 1-7, 2017.

[9] Bhalerao MS, Bolshete PM, Swar BD, Bangera TA, Kolhe VR, Tambe MJ, et al. Use of and satisfaction with complementary and alternative medicine in four chronic diseases : A cross-sectional study from India, Nati Med $J$ India, 26(2), pp. 75-8, Maret-April, 2013.

[10] Mollaoğlu M, Aciyurt A. Use of complementary and alternative medicine among patients with chronic diseases. Acta Clin Croat, 52(2):181-8, 2013.

[11] National Center for Complementary and Integrative Health. Complementary, Alternative, or Integrative Health: What's In a Name? Nccih. 2015.

[12] Moolasarn Summana, et al., Usage of and Cost of Complementary/Alternative Medicine in Diabetic Patients, $J$ Med Assoc Thai, Vol. 88, No. 11, pp. 1630-7, 2005.

[13] Kumar D, Bajaj S, Mehrotra R. Knowledge, attitude and practice of complementary and alternative medicines for diabetes. Public Health, Vol. 120(8), pp. 705-11, 2006.

[14] Bell RA, Suerken CK, Grzywacz JG, Lang W, Quandt SA, Arcury TA. Complementary and alternative medicine use among adults with diabetes in the United States. Altern Ther Health Med. Vol 12, No. 5, pp. 16-23, 2006.

[15] Ceylan S, Azal Ö, Taşlipinar A, Türker T, Açikel CH, Gulec M. Complementary and alternative medicine use among Turkish diabetes patients. Complement Ther Med, Vol. 17, No. 2, pp. 78-83, 2009.

[16] Khalaf AJ, Whitford DL. The use of complementary and alternative medicine by patients with diabetes mellitus in Bahrain: A cross-sectional study, BMC Complement Altern Med, 10(35), pp. 1-5, 2010.

[17] Hsiao-yun AC, Wallis M, Tiralongo E. Use of Complementary and Alternative Medicine among People with Type 2 Diabetes in Taiwan: A Cross-Sectional Survey, Evid - Based Complement Altern Med, pp 1-8, 2011.

[18] Ali-shtayeh MS, Jamous RM, Jamous RM. Complementary Therapies in Clinical Practice Complementary and alternative medicine use amongst Palestinian diabetic patients. Complement Ther Clin Pract, 18(1):16-21, 2012.

[19] Manya K, Champion B, Dunning T. The use of complementary and alternative medicine among people living with diabetes in Sydney. BMC Complement Altern Med,12(1):2, 2012.

[20] Fan PEM, Chan MF, Chan YL, Koh SLS. Patterns of complementary and alternative medicine use among a group of patients with type 2 diabetes receiving outpatient care in Singapore, Int J Nurs Pract, 19(SUPPL.3):44-55, 2013.

[21] Villa-caballero L, Morello CM, Chynoweth ME, Prieto-rosinol A, Polonsky WH, Palinkas LA, et al. Ethnic differences in complementary and alternative medicine use among patients with diabetes. Complement Ther Med, 18(6):241-8, 2010.

[22] Chang H-YA, Wallis M, Tiralongo E. Predictors of complementary and alternative medicine use by people with type 2 diabetes. $J$ Adv Nurs, 68(6):1256-66, 2012.

[23] Hashempur MH, Heydari M, Mosavat SH, Heydari ST, Shams M. Complementary and alternative medicine use in Iranian patients with diabetes mellitus. J Integr Med, 13(5):319-25, 2005.

[24] Chang $\mathrm{H}$, Wallis M, Tiralongo E. Use of complementary and alternative medicine among people living with diabetes: literature review. J Adv Nurs, 58(4):307-19, 2007.

[25] Canaway R, Manderson L, Oldenburg B. Perceptions of benefit of complementary therapy use among people with diabetes and cardiovascular disease, Forsch Komplementarmed, 21(1):25-33, 2014.

[26] Hasan SS, Loon WC, Ahmadi K, Ahmed SI, Bukhari NI. Reasons, perceived efficacy and factors associated with complementary and alternative medicine use among Malaysian patients with diabetes mellitus. Br J Diabetes Vasc Dis, 11(2):92-8, 2011. 
[27] Naja F, Mousa D, Alameddine M, Shoaib H, Itani L, Mourad Y. Prevalence and correlates of complementary and alternative medicine use among diabetic patients in Beirut, Lebanon: A cross-sectional study. BMC Complement Altern Med, 14(1):1-11, 2014.

[28] Kim H.J., Chun K.H., Kim D.J., Han S.J., Kim Y.S., W., J.T., Park Y., Nam M.S., Baik S.F., Ahn K.J., Lee K.W., Utilization patterns and cost of complementary and alternative medicine compared to conventional medicine in patients with type 2 diabetes mellitus. Diabetes Research and Clinical Practice, 93: 115-122, 2011

[29] Fabian E, Töscher S, Elmadfa I, Pieber TR. Use of complementary and alternative medicine supplements in patients with diabetes mellitus. Ann Nutr Metab, 58(2):101-8, 2011.

[30] Funnell MM, Brown TL, Childs BP, Haas LB, Hosey GM, Jensen B, et al. National standards for diabetes selfmanagement education. Diabetes Care. 2012.

[31] Mitha S, Nagarajan V, Gohar M. Reasons of using complementary and alternative medicines ( CAM ) among elderly Malaysians of Kuala Lumpur and Selangor states : An exploratory study. J Young Pharm, 5(2):50-3, 2013.

[32] Chew BH, Ming KE, Chia yook C. Social support and glycemic control in adult patients with type 2 diabetes mellitus, Asia Pac J Public Health, 27(2):166-73, 2011.

[33] Honda K, Jacobson JS. Use of complementary and alternative medicine among United States adults: The influences of personality, coping strategies, and social support, Prev Med (Baltim), 40(1):46-53, 2005.

[34] Mann, JD., Gaylord, SA., and Norton, SK., Integrating Complementary \& Alternative Therapies With Conventional Care (The Convergence of Complementary, Alternative and Conventional Health Care: Educational Resources for Health Professionals), University of North Carolina at Chapel Hill, Program on Integrative Medicine. 2004 